\title{
Penerapan Metode Bernyanyi Pada Pembelajaran Tajwid Di Rumah Qur'an An-nur Banjarmasin
}

\author{
Muhammad Iqbal Ansari \\ Universitas Islam Kalimantan Muhammad Arsyad Al Banjari \\ Email: muhammadiqbalansari13@gmail.com
}

\begin{abstract}
Abstrak
Salah satu kesulitan peserta didik dalam belajar ilmu tajwid adalah ketidak sesuaian gaya belajarnya dengan metode yang diterapkan. Olehsebabitu guru harus mengajar dengan metode yang mengakomodasi berbagai gaya belajar. Metode yang dianggap sangat representative adalah metode bernyanyi.

Penelitian ini bertujuan mendeskripsikan penerapan metode bernyanyi pada pembelajaran tajwid di Rumah Qur'an An-Nur Banjarmasin serta mengungkap kendala yang dihadapi. Penelitian ini menggunakan pendekatan kualitatif dengan jenisstudi kasus. Data primer yang digunakan ialah narasumber, aktivitas, dan lokasi.Analisis dilakukan melalui proses pengumpulan, reduksi, paparan, verifikasi data,dilanjutkan pengambilan kesimpulan. Validitas data dilakukan dengan triangulasi.

Hasil penelitian menunjukkan bahwa sistem pembelajaran terdiri dari:1) perencanaan melalui penunjukkan beberapa guru mengikuti pelatihan pembelajaran tajwid dengan metode bernyanyi Fun Tahsin,2) Pengorganisasian dilakukan dengan memberikan tanggung jawab kepada guru yang diberi pelatihan menjadi Divisi Akademik dan mengajarkan metode bernyanyi kepada guru lainnya, 3) pelaksanaan pembelajaran dilakukan dengan metode sam'iyyah syafawiyyah yaitu dengan memperdengarkan materi lagu dan dilanjutkan dengan menyanyikan materi yang didengar oleh peserta didik, dan 4) evaluasi yang dilaksanakan dengan 2 cara, yaitu formatif dan sumatif. Kendala yang dihadapi pada proses pembelajaran dengan metode bernyanyi ialah ketidakhadiran peserta didik dan guru yang masih kurang ekspresif dan malu-malu mengajar dengan cara bernyanyi.
\end{abstract}

Kata Kunci: Bernyanyi, Pembelajaran Tajwid, Rumah Qur'an

Vol. 1, No. 2, Desember 2019 


\section{PENDAHULUAN}

Berdasarkan hasil sensusnasional oleh Badan Pusat Statistik (BPS) pada 2013 yang dikutip oleh Republika dalamartikel Buta Aksara Alquran Masih Tinggi, ditemukan bahwa dari sekitar 225 juta populasi muslim di Indonesia, 54\% dikategorikan buta huruf Al-Quran. Data berbeda ditemukan oleh Perguruan Tinggi Ilmu Quran (PTIQ) yang menunjukkan bahwa $65 \%$ masyarakat Indonesia masih buta aksara Al-Quran, terutama di daerah pelosok. (Republika, 2018). Kedua data tersebut berbeda, namun sama pada substansinya, yaitu setengah warga muslim di Indonesia belum bisa baca tulis Al-Qur'an.

Data di atas menimbulkan pertanyaan "apa yang menyebabkan umat Islam tidak mampu membaca Al-Qur'an?”. Dari hasil penelitian Pratiwi(2017) mengenai analisis kesulitan belajar Al-Qur'an ditemukan bahwa kesulitan yang dirasakanseseorang ketika belajar membaca Al-Qur'an adalah: 1)kesulitan menghafal disebabkanpersamaan ciri dan bentuk pada beberapa huruf hijaiyah, 2)kesulitan memahamiperubahan bentuk huruf hijaiyah yang bersambung, 3) kesulitan membedakan harakatpanjang dan pendek, kesulitan pengucapan makhraj yang benar, dan 4) kesulitandalam penerapan hukum tajwid.Penelitian juga menemukan faktorfaktor penyebab kesulitan seseorangdalam belajar Al-Qur'an diantaranya ialah ketidaksesuaian gaya belajar siswa dengan metode yang digunakan guru.Sebuah artikel yang ditulis pada laman web Ruangguru.com memaparkan bahwa salah satu hal yang membuat seseorang kesulitan untuk belajar adalah karena ketidaksesuaian gaya belajarnya dengan metode yang digunakan oleh guru.

Jika hasil penelitian di atas dianalisa, maka penyebab seseorang tidak mampu membaca Al-Qur'an adalah karena tingkat kesulitan materi, baik itu bentuk dan pengucapan huruf. Dan penyebab berikutnya adalah stigma bahwa belajar Al-Qur'an dilaksanakan dengan metode yang kurang sesuai dengan gaya belajar peserta didik, sehingga tentu membuat persepsi pada sebagian orang bahwa pembelajaran AlQur'an itu kurang menyenangkan. 
Stigma bahwa belajar Al-Qur'an itu tidak menyenangkan mungkin didasari bahwa pada beberapa sekolah, pembelajaran Al-Qur'an dilaksanakan dengan kegiatan yang terkesan monoton, yaitu diawali dengan membaca doa, kemudian membacakan Al-Qur'an di depan guru yang jika bacaan salah maka akan ditegur dan disuruh mengulang, atau bahkan tanpa dikoreksi sama sekali. Selanjutnya diberi nilai dan ditutup dengan doa. Adapun teori tajwid hanya diajarkan melalui metode ceramah yang dibarengi dengan contoh pelafalannya dan sesekali peserta didik diminta menirukan.

Pemahaman peserta didik mengenai tajwid di Pondok Pesantren Tahaffudzul Qur'anPurwoyoso Ngaliyan Semarang lebih rendah daripada prakteknya. Artinya ada sesuatu yang harus diperbaiki agar pemahaman peserta didik sebanding dengan prakteknya. $^{1}$

metode pembelajaran mempunyaikorelasidengan gaya belajar. Oleh sebab itu, guru harus menerapkan metode pembelajaran yangbermaca-macamuntuk mengakomodir ragamgaya belajar siswanya. Hasil penelitian Fuad senada dengan penelitian yang dilakukan oleh Bire dan Halim yang juga menympulkan bahwa gaya belajar sangat berpengaruh terhadap keberhasilan proses pembelajaran.

Gaya belajar terbagi ke dalam 3 tipe yaitu gaya belajar visual (melihat), auditorial (mendengar), dan kinestetik (bergerak).Jika memperhatikanteori gaya belajar tersebut, berarti seorang pendidik harus menggunakan metode yang mengakomodasi ketiga gaya tersebut dalam setiap pembelajaran, tidak terkecuali pada pembelajaran Al-Qur'an. Dalam menentukan metode, pendidik harus memahami materi yang akan disampaikan dan mengerti karakteristik peserta didik agar capaian pembelajara nmaksimal. ${ }^{2}$

${ }^{1}$ Hidayati, A. Studi Analisis Pemahaman Santri TentangMateri Tajwid dan Gharib di PondokPesantren Putri Tahaffudzul Qur'anPurwoyoso Ngaliyan Semarang. Skripsi UIN Wali Songo Semarang.2015

${ }_{2}^{2}$ B DePorter, \& MohHernacki, Quantum Learninng: Membiasakan Belajar Nyaman dan Menyenangkan. (Bandung: Kaifa Learning,2015),hal,42 
Oleh sebab itu dalam pembelajaran Al-Qur'an, guru harus memilih metode yang sesuai dengan pokok bahasan dan memiliki cara-cara yang menarik sehingga peserta didik termotivasi terhadap pembelajaran.

Berdasarkan observasi peneliti, Rumah Qur'an An-Nur Banjarmasin merupakan salah satu lembaga pendidikan yang unik dalam melaksanakan pembelajaran Al-Qur'an, yaitu melaluiFun Tahsin.Fun Tahsin merupakan sebuah metode pembelajaran yang menyampaikan materi tajwid melalui gerak dan lagu kepada pesertadidik, sehingga suasana kelas lebih meriah dan menyenangkan.

Metode Fun Tahsinadalah sebuah inovasi yang dikembangkan oleh Yudi Imana guna mempermudah para umat muslim dalam proses belajar dan mengajar AlQur'an dengan baik dan benar. Fun Tahsin merupakan dua kata serapan yaitu Fun dari bahasa Inggris yang berarti menyenangkan, dan Tajwidyang berasal dari bahasa Arab yang berarti memperbaiki atau membaguskan. ${ }^{3}$

Metode ini merupakan suatu metode dalam pembelajaran tajwid yang mengajarkan kaidah tajwid dengan nyanyian dan gerak, sehingga para peserta didik aktif secara visual, audio, dan kinestetik, sesuai dengan kaidah pembelajaran active learning yang dianggap sangat cocok untuk peserta didik usia SD/MI. ${ }^{4}$

Metode menyanyi dianggap efektif dalam pembelajaran untuk anak usia SD/MI. hal Ini berdasarkan penelitian Zuraida (2017), dengan sumber data kelas IV SD Muhammadiyah Ambarketawang 3, ditemukan bahwa penerapan pembelajaran dengan menggunakan metode bernyanyi meningkatan aktivitas belajar peserta didik.Pada penelitian lain, Ervina (2015) yang meneliti menggunakan metode eksperimen menemukan bahw anak pada kelas eksperimen yang menggunakan metode bernyanyi memiliki nilai rata-rata lebih tinggi jika dibandingkan dengan anak

\footnotetext{
${ }^{3}$ Imana, Y. (2015). Metode Asyaroh Fun Tahsin. (Bandung: Menara Al-Qur'an Press.2015),hal, 14

${ }^{4}$ Machmudah, U. \& Rosyadi, A.W. Active Learning dalam Pembelajaran Bahasa Arab. (Malang: UIN Malang Press.2010),hal,71
} 
pada kelas kontrol yang menggunakan metode konvensional. Hipotesis penelitian ini adalah metode bernyanyi efektif terhadap pengenalan huruf hijaiyah anak.

Ridwan, dkk (2019) pada hasil penelitiannya memaparkan bahwa penggunaan teknik bernyanyi dalam pembelajaran bahasa Arab sebagai bahasa Al-Qur'an merupakan solusi alternatif dalam mengatasi kesulitan belajar peserta didik usia sekolah dasar karena sejatinya anak-anak suka bernyanyi.

Berdasarkan paparan di atas, peneliti tertarik untuk melakukan sebuah penelitian dengan tujuan mendeskripsikan penerapan metode bernyanyi pada pembelajaran tajwid di Rumah Qur'an An-Nur Banjarmasin serta mengungkap kendala-kendala yang dihadapi.

\section{METODE PENELITIAN}

Penelitian ini berjudul "Penerapan Metode Bernyanyi pada Pembelajaran Tajwid di Rumah Qur'an An-Nur Banjarmasin”. Penelitian ini menggunakan pendekatan kualitatif yaitu sebuah prosedur penelitian yang menghasilkan data deskriptif berupa kata-kata tertulis atau lisan dari orang-orang dan perilaku yang dapat diamati dan diarahkan pada latar dan individu secara utuh. ${ }^{5}$ Yang berarti penelitian ini berusaha mencari gambaran mengenai penerapanmetode bernyanyi pada pembelajaran tajwid di Rumah Qur'an An-Nur Banjarmasin serta mengungkap kendala-kendala yang dihadapi.

Adapun jenis penelitian yang digunakan dalam penelitian ini ialah studi kasus(case studies). Menurut Ghonydan Fauzan, Studi Kasus (case study) merupakanpenelitian tentang sesuatu "kesatuan sistem." Kesatuan ini dapat berupa program,kegiatan, peristiwa, atau sekelompok individu yang terkait oleh tempat, waktu, danikatan tertentu.

Dilihat dari kasus yang diteliti, menurut Endraswara dalam Mudjia (2017), Studi Kasus dapatdibagi menjadi dua golongan, yaitu Studi Kasus berupa

\footnotetext{
${ }^{5}$ J Lexi Moleong, Metodologi Penelitian Kualitatif. (Bandung: Rosdakarya.2011),hal,21
} 
penyimpangan dari kewajaranataudisebut dengan Studi Kasus Retrospektif dan Studi Kasus ke arah perkembanganyang positif atauStudi Kasus Prospektif.Adapun pada penelitian ini diarahkan pada jenis yang kedua yaitu StudiKasusProspektif, yaitu berupaya menemukan kecenderungan dan arah perkembangan suatukasus. Tindak lanjutnya berupa Penelitian Tindakan (Action Research) yang dilakukanjuga oleh pihaklain yang berkompeten.

Penelitian ini dilakukan di Rumah Qur'an An-Nur Kota Banjarmasin,Provinsi Kalimantan Selatan. Pengumpulan data dilakukan dengan teknik wawancara, observasi, dan dokumentasi. Teknik wawancara dilakukan untuk mendapatkan data lisan dari sumber datayaitu Kepala Rumah Qur'an An-Nur, Kepala Divisi Akademik, Koordinator, dan tenaga pengajar.Bentuk interview yangdigunakan penelitimelaluiwawancara bebas dan terpimpin. Dalaminterview bebas terpimpin ini pewawancara sudah mempersiapkan pertanyaan secaralengkap dan cermat.

Teknik observasi dilakukan untuk mendapatkan hasil pengamatan melalui penglihatan maupun pendengaran secara langsung ketika pembelajaran dilaksanakan. dalam penelitian ini, seorangpeneliti kualitatif langsung terlibat dalam setting sosial.Sedangkan dokumentasi dilakukan untuk mengambil data berupa rekaman wawancara, foto, atau video selama penelitian. ${ }^{6}$ Melalui dokumentasi, peneliti juga mencoba mengumpulkan data berupa buku referensi yang digunakan oleh guru dalam memberikan pelajaran, profil sekolah, dan lain-lain.

Adapun analisis data dalam penelitian kualitatif ini bersifat iteratif (berkelanjutan) dan dikembangkan sepanjang penelitian. Analisis dilakukan mulai tahapan pengumpulan data, reduksi data, paparan data, serta verifikasi dan pengambilan kesimpulan. Pengecekan keabsahan data dilakukan dengan triangulasi sumber, teknik, dan waktu. ${ }^{7}$

\section{HASIL PENELITIAN DAN PEMBAHASAN}

\footnotetext{
${ }^{6}$ Somantri, Memahami Metode Kualitatif. Jurnal Makara Seri Sosial Humaniora,hal,65

${ }^{7}$ Mujia Rahardjo, Studi Kasus dalam Penelitian Kualitatif: Konsep dan Prosedurnya.(UIN Press,2017), hal, 34
} 
Rumah Qur'an An-Nur didirikan pada tahun 2017 di bawah Yayasan H.Norsidi. Lembaga ini berlokasi di Jl. Pramuka Kelurahan Pemurus Luar Kota Banjarmasin. Pendirian lembaga ini bermula dari inisiasi $\mathrm{Ibu} \mathrm{Hj}$. Nurani untuk membangun sebuah lembaga pendidikan Al-Qur'an yang disampaikan kepada Ust. Reza Ferdian. Pendirian lembaga ini juga dalam mendukung Peraturan Daerah (Perda) Kalimantan Selatannomor 3 tahun 2009 tentang wajib belajar Al-Qur'an di sekolah umum mulai tahun ajaran 2010-2011. Adapun tujuan dari lembaga ini yaitu 1) membentuk Generasi Qur'ani (CintaQur'an) yang berakhlak mulia, 2) Menciptakan kaderisasi huffazh (penghafal Al-Qur'an)yang memahami fiqh dengan benar, 3) memberdayakan potensi anak, dan 4) Memberdayakan profesionalisme guru Al-Qur'an. (Ansari, 2018)

Selanjutnya Ust. Reza Ferdian mengajak Ust.Fakhri Hanief untuk turut serta membangun lembaga ini dan mengembangkannya hingga memiliki lebih banyak santri. Awal dibangun, jumlah santri hanya sekitar 120 orang yang dilaksanakan hanya pada 1 shift, yaitu pada malam senin, rabu, dan jum'at. Namun seiring permintaan masyarakat, pada tahun 2018, ditambah lagi shift kedua dengan jumlah satri yang hampir sama. Shift kedua ini dilaksanakan pada malam selasa, kamis, dan sabtu. Pada tahun 2019, dilaksanakan Wisuda I Rumah Qur'an An-Nur di sebuah gedung di kota Banjarmasin dan menampilkan hasil dari santri-santri yang mengikuti pendidikan Al-Qur'an di lembaga ini. Setelah kegiata wisuda, daftar tunggu santri semakin bertambah, maka dibentuk lagi shift yang dilaksanakan pada sore hari, yaitu pada hari senin, rabu, dan jum'at.Shift 1 terdiri dari 23 kelompok, shift 2 terdiri 13 kelompok, dan shift sore 7 kelompok. Setiap kelompok terdiri terdiri dari 12-15 peserta didik. Total peserta didik pada tahun 2019 ialah 549 orang.

Perkembangan di atas menunjukkan bahwa Rumah Qur'an An-Nur setiap tahun semakin dipercaya oleh masyarakat dalam pendidikan Al-Qur'an. Selain itu konsistensi jumlah santri yang tetap bertahan untuk belajar di Rumah Qur'an An-Nur juga menunjukkan bahwa tingkat kepuasan masyarakat pada proses pembelajaran 
sangat tinggi. Hal ini sebagaimana yang disampaikan oleh Ust. Fakhri Hanief selaku Kepala Rumah Qur'an An-Nur, bahwa pihak pengelola berupaya selalu memperbaiki proses pembelajaran agar tidak membosankan dengan membina tenaga pengajar agar melaksanakan pembelajaran sesuai dengan perkembangan peserta didik yang $70 \%$ merupakan usia SD/MI.

Di antara upaya yang dilakukan untuk membuat proses pembelajaran semakin variatif ialah dengan mengikutsertakan beberapa tenaga pengajar Rumah Qur'an AnNur pada pelatihan-pelatihan pembelajaran Al-Qur'an, di antaranya ialah pengiriman 3 tenaga pengajar untuk mengikuti pelatihan Fun Tahsin yang dilaksanakan pada tahun 2017. Dan pelatihan ini dibimbing langsung oleh penyusun Fun Tahsin, yaitu Ust.Yudi Imana. Ketiga tenaga pengajar yang mengikuti pelatihan kemudian dijadikan sebagai anggota Divisi Akademik dan kemudian diminta untuk memberikan pelatihan kepada tenaga pengajar yang lain. Sehingga setiap guru mampu menerapkan pembelajaran Fun Tahsin di kelas masing-masing.Pelatihan dilaksanakan melalui kegiatan yang berisi pemberian materi Fun Tahsin, praktik menyanyi, dan praktik mengajar.

Awalnya pemberian materi Fun Tahsin kepada peserta didik dilaksanakan secara klasikal seluruh kelompok, yaitu pada pukul 18.00 sebelum shalat maghrib untuk shift malam atau pada pukul 15.30 sebelum shalat ashar untuk shift sore. Pemberian materi Fun Tahsin tesebut juga hanya diajarkan oleh guru tertentu dan hanya dilaksanakan setiap 1 kali dalam seminggu.

Selama 1,5 tahun digunakan, sistem seperti ini dianggap kurang efektif karena dalam bentuk klasikal, hanya beberapa peserta didik yang memperhatikan dan terevaluasi dengan baik. Akhirnya sistem pembelajaran dirubah di mana pembelajaran Fun Tahsin dilaksanakan oleh setiap guru di kelompok masing-masing dan dilaksanakan pada setiap kali pertemuan.

Pengelola Rumah Qur'an An-Nur melakukan pengendalian pembelajaran melalui evaluasi. Evaluasi dilakukan dengan mengambil data dari para guru dan 
kemudian dibahas oleh Divisi Akademik yang kemudian ditindaklanjuti dengan refleksi dalam bentuk perubahan sistem. Hal ini sesuai dengan penelitian yang dilakukan Ansari (2018) pada pembelajaran Al-Qur'an metode At-Tibyan bahwa untuk mengetahui ketercapaian tujuanpembelajaran guru dapat menggunakan berbagai alat penilaian, misalnya mengunakan hasil diagnosa guru terhadap peserta didik di kelompoknya. Hasil evaluasi dimanfaatkan guru sebagai refleksi untukmemperbaiki kegiatan pembelajaran.

Berdasarkan hasil observasi di kelas dan wawancara peneliti dengan Koordinator Kelompok dan guru, diperoleh data bahwa kegiatan pembelajaran Fun Tahsin di Rumah Qur'an An-Nur dilaksanakan dengan langkah-langkah sebagai berikut:

1. Pertama-tama guru mengkondisikan peserta didik melalui ice breaking seperti ucapan "Guru: mana rapimu? Siswa: inirapiku. Guru: mana buktinya? Siswa: inibuktinya”. Kemudian guru menuliskan materi lagu Fun Tahsin missal materi “Al-Jauf”di papan tulis, kemudian membacakan secara berulang-ulang dengan irama tanpa gerakan secara perlahan sedangkan peserta didik memperhatikan.

2. Setelah langkah 1, guru mengajak peserta didik untuk mengikuti nyanyian bait perbait. Jika peserta didik dirasa sudah menguasai, guru melanjutkan pada bait berikutnya hingga selesai satu materi lagu. Pada langkah ini, lagu belum disertai dengan gerakan.

3. Langkah berikutnya, guru meminta peserta didik untuk menyanyikan lagu bersama-sama. Kemudian peserta didikdi kelas dibagi kepada 3 kelompok, 1 kelompok dari 4-5 orang. Kemudian masing-masing kelompok diminta untuk menyanyikan lagu bersama-sama.

4. Selanjutnya guru mencontohkan menyanyikan lagu disertai dengan gerakan. Proses samadenganlangkah 2, yaitu guru mencontohkan perbait, namun kali ini disertai dengan gerakan. 
5. Langkah berikutnya guru melaksanakan proses pembelajaransepertipadalangkah 3. Namun kali ini perbedaannya yaitu peserta didik harus menggunakan gerakan.

6. Isi materi lagu seperti "Al-Jauf" yang berisi kaidah mad ashli kemudian dipraktekkan dalam membaca Surah Al-Fatihah atau surah lain yang ada mad Ashli-nya.

Metode Audio-lingual ini termasuk metode terbaik yang menggambarkan pendekatan aliran aural-oral approch. Metode ini mencerminkan pertemuan antara teori aliran behaviorisme dalam psikologi dan teori struktural dalam linguistik. Dianggap teraik karena metode ini mengutamakan proses menyimak terlebih dahulu, baru kemudian dilanjutkan dengan melafalkan atau menyanyikan materi yang dipelajari.

Pengaruh metode ini berdasarkan hasil penelitian Tajjri sangat positif. Data yang diperoleh menunjukkan bahwa penggunaan metode sam'iyyah syafawiyyah meningkatkan hasil belajar peserta didik pada mata pelajaran bahasa arab di MI Azizan. Metode ini dianggap mengaktifkan proses pembelajaran dari awal hingga akhir. $^{8}$

Buku referensi yang digunakan dalam menerapkan Fun Tahsin ialah buku Kumpulan Materi Ta'lim karya Fakhri Hanief, dkk yang berisi materi Fun Tahsin karya Yudi Imana.Dan berikut adalah materi metode bernyanyiFun Tahsin yang diajarkan di Rumah Qur'an An-Nur Banjarmasin:

${ }^{8}$ Muh Tajjri, Penerapan Metode Sam'iyyah Syafawiyah Terhadap Hasil Belajar Siswa Kelas III dada Mata Pelajaran Bahasa Arab di MI Azizan Palembang. SkripsiUIN Raden Fatah Palembang.2016 
BADA'A: Jurnal Ilmiah Pendidikan Dasar

Vol. 1, No. 2, Desember 2019, Hal.124-139

\begin{tabular}{|l|l|}
\hline \multicolumn{1}{|c|}{ Materi } & \multicolumn{1}{|c|}{ Isi } \\
\hline Fun Tahsin I & a. Materi Vokal \\
& b. Al-Jauf/Rongga Mulut \\
& c. Al Khaisyum/Rongga Hidung \\
& d. Materi Izhar \\
\hline Fun Tahsin II & a. Huruf Hijaiyyah \\
& b. Sifat Yang Memiliki Lawan Kata \\
& c. Sifat yang tidak memiliki lawan kata \\
\hline Fun Tahsin III & a. Teknik Madd \\
& b. Macam-Macam Madd Far'i \\
& c. Teknik Ghunnah \\
& d. Teknik Qalqalah \\
& e. Teknik Lam Ta'rif \\
& f. Teknik Idgham \\
\hline Fun Tahsin IV & a. Teknik Lafazh Allah \\
& b. Teknik Hukum Ra' \\
& c. Teknik Ayat Gharibah \\
& d. Teknik Waqaf Wal Ibtida \\
\hline
\end{tabular}

Salah satu contoh lirik lagu Fun Tahsin, yaitu materi Al-Jauf, yang berarti rongga mulut. Materi mengajarkan peserta didik untuk mampu mengukur panjang bacaan 2 harakat dengan baik dengan gerakan tangan ke depan dan ke belakang. Berikut lagu "Al-Jauf” yang dinyanyikan dengan irama lagu "Balonku”:

"Al-Jauf, Rongga Mulut

Yang keluar Madd, hurufnya:

Alif setelah fathah

Ya sukun setelah kasrah

Waw sukun setelah dhammah

Kasrah berdiri, fathah berdiri

Dhammah terbalik

Diayun 2 harakat"

Sebagaimana peribahasa yang berbunyi "Tak ada gading yang tak retak", maka sama halnya pada pembelajaran Fun Tahsin ini. Berdasarkan hasil wawancara dan observasi, kendala yang mengganggu prose pembelajaran ialah peserta didik yang datang terlambat atau tidak masuk, sehingga peserta didik tersebut tidak menguasai materi dengan baik. 
Peneliti juga menanyakan apakah peserta didik tergolong hyperactive mengganggu proses pembelajaran? Ternyata berdasarkan hasil wawancara dan observasi, hal tersebut tidak terganggu, karena pembelajaran yang aktif sangat sesuai dengan gaya belajar anak yang tergolong sangat aktif. Data ini sesuai dengan hasil penelitian Puteri (2013)yang menunjukkan bahwa metode bernyanyi meningkatkan kemampuan bahasa anak yang aktif.

Kemudian bagaimana dengan anak yang pendiam? Hasil pengamatan juga menunjukkan bahwa anak yang pendiam juga terlibat aktif dalam pembelajaran, karena suasana seluruh kelas yang meriah membuat dia mau tidak mau terlibat di dalamnya.

Kendala juga terjadi pada guru. Tipikal guru yang pendiam, malu-malu, dan kurang ekspresif membuat pembelajaran menyanyi sedikit kaku dan kurang meriah. Namun setidaknya, melaluimetode bernyanyi, kinerja guru dengan tipikal seperti ini lebih aktif daripada menggunakan metode ceramah. Tentu hal ini mempengaruhi proses dan hasil belajar siswa. Hal ini selaras dengan penelitian yang dilakukan oleh Laksono (2016) yang menunjukkan bahwa kinerja guru berpengaruh terhadap hasil belajar siswa di SD Segugus Bima.

Penguasaan peserta didik terhadap materi Fun Tahsin yang diajarkan dievaluasi setelah pembelajaran dan pada setiap akhir semester. Evaluasi dilakukan dengan tes menyanyikan secara hafalan dan gerakan. Berikutnya ialah tes pertanyaan hubungan antara bacaan Al-Qur'an dengan teori Fun Tahsin yang diajarkan.

Evaluasi formatifdimaksudkan untuk mengetahui sejauh manapeserta didikterbentuk setelah mengikuti suatuprogram tertentu. evaluasi atau tes formatif diberikanpada akhirsetiap program pembelajaran. Tes formatifsering disamakan dengan ulangan harian (kuis)kegiatan yang dilakukan secara periodik untukmengukur pencapaian kompetensi mahasiswasetelah menyelesaikan satu atau lebih kompetensiyang menjadi target ketercapaian programpembelajaran. Namun dalam metode bernyanyi ini, Rumah Qur'an An-Nur melaksanakan tes formatif dalam 


\section{BADA'A: Jurnal Ilmiah Pendidikan Dasar}

Vol. 1, No. 2, Desember 2019, Hal.124-139

bentuk perkelompok yang terdiri dari 4-5 peserta didik, kemudian setelah itu diuji secara individu. ${ }^{9}$

Evaluasi atau tes sumatif dilaksanakan setelahberakhirnya pemberian sekelompok program atausebuah program yang lebih besar. Tes sumatif dapatdilaksanakan dengan ujian akhir semester (UAS). Tesdalam rangka pendidikan digunakan untukmemperoleh bukti tentang taraf keberhasilan prosesbelajar mengajar.

${ }^{9}$ S,F Selegi, Model Evaluasi Formatif-Sumatif Terhadap MotivasiBelajar MahasiswaPada Mata Kuliah Perencanaan Pengajaran Geografi. Prosiding Seminar Nasional 20 Program Pascasarjana Universitas PGRI Palembang. 2017 


\section{KESIMPULAN}

Berdasarkan pemaparan di atas, maka dapat disimpulkan beberapa hal sebagaiberikut:

1. Penerapan pembelajaran tajwid dengan metode menyanyi dilakukan dengan beberap atahapan sesuai dengan teori manajemen pembelajaran, yaitu:

a. Perencanaan dan Persiapan. Tahapan ini dimulai dengan perencanaan bahwa setiap guru harus diberikan pelatihan untuk meningkatkan kualitas pembelajaran. Oleh karena itu perlu dipersiapkan guru dengan mengikutsertakan beberapa guru untuk mengikuti pelatihan metode mengajar Tajwid dengan menyanyi, yaitu Fun Tahsin.

b. Pengorganisasian. Guru yang telah mendapat pelatihan dari kegiatan Fun Tahsin dijadikan sebagai anggota Divisi Akademik dan bertanggungjawab untuk memberikan pelatihan kepada guru-guru yang lain. Pelatihan dilaksanakan dengan pemberian materi, tes penguasaan materi, dan dilanjutkan dengan praktik mengajar (micro teaching).

c. Pelaksanaan. Kegiatan metode menyanyi di kelas dilaksanakan dengan menggunakan metode sam'iyyahsyafawiyyah, yaitu metode yang lebih mengedepankan indera pendengaran peserta didik terlebih dahulu dalam menerima materi, baru dilanjutkan dengan pengucapannya. Langkahlangkahnya dimulai dengan guru terlebih dahulu memperdengarkan materi lagu beberapa kali, kemudian peserta didik dibimbing untuk mengucapkan atau menyanyikan lagu.

d. Evaluasi. Evaluasi pembelajaran dilaksanakan dengan 2 cara, yaitu formatif dan sumatif. Formatif dilakukan setiap selesai pembelajaran dalam bentuk perkelompok yang terdiri dari 4-5 peserta didik, kemudian setelah itu dilanjutkan tes secara individu. Sedangkan sumatif dilaksanakan pada setiap akhir semester. Hasil kedua tes ini akan dijadikan sebagai bahan refleksi pada rencana pembelajaran pada semester berikutnya. 


\section{BADA'A: Jurnal Ilmiah Pendidikan Dasar}

Vol. 1, No. 2, Desember 2019, Hal.124-139

2. Adapun kendala yang dihadapi dalam pembelajaran ini terbagi dua, yaitu pada peserta didik dan guru. Peserta didik yang dating terlambat dan tidak hadi rmembuat pembelajaran kembali terulang atau jika tetap diteruskan makapeserta didik yang terlambat tidak terlalu menguasai materi. Adapun masalahpada guru ialah beberapa guru masih malu-malu dan kurang ekspresif dalam mengajar dengan cara bernyanyi. 


\section{DAFTAR PUSTAKA}

M Iqbal Ansari, M.I. Sistem Karantina Tahfidzh 1 Hari untuk Anak Usia SD/MI diRumah Tahfidzh Al-Haramain. Jurnal Al Ibtida: Jurnal Pendidikan Guru MI. Vol 5 (2) : 205-220. ISSN: 2442-5133, e-ISSN: 2527-7227. 2018

A.L,Bire, Pengaruh Gaya Belajar Visual, Auditorial, dan Kinestetik Terhadap Prestasi Belajar Siswa. Jurnal Kependidikan, 44(No 2), 168-174.2014

B DePorter, . \& M Hernacki. Quantum Learninng: Membiasakan Belajar Nyaman dan Menyenangkan. Bandung: Kaifa Learning.2015

W Ervina, Efektivitas Metode Bernyanyi Terhadap Pengenalan Huruf Hijaiyyah di Taman Kanak-kanak Bhayangkari 3 Padang. Jurnal Pesona Paud: Pendidikan Guru Pendidikan Anak Usia Dini, Fakultas Ilmu Pendidikan, Universitas Negeri Padang. ISSN 2337-8301.2015

A.J Fuad, Gaya Belajar Kolb dan PercepatanBelajar, Psychology Forum UMM. ISBN:978-979-796-324-8. 2015

Hidayati, A. (2015). Studi Analisis Pemahaman Santri TentangMateri Tajwid dan Gharib di PondokPesantren Putri Tahaffudzul Qur'anPurwoyoso Ngaliyan Semarang. Skripsi UIN Wali Songo Semarang.

Y Imana, Metode Asyaroh Fun Tahsin. Bandung: Menara Al-Qur'an Press. 2015

C.T.Laksono, Pengaruh Kinerja Guru Terhadap Prestasi Belajar Matematika Siswa Kelas V Se Gugus Bima Tahun Ajaran 2015/2016.SkripsiFakultas Ilmu Pendidikan Universitas Negeri Yogyakarta.2017

U. Machmudah, \& A Rosyadi, Active Learning dalam Pembelajaran Bahasa Arab. Malang: UIN Malang Press.2010

J.L.Moleong, Metodologi Penelitian Kualitatif. Bandung: Rosdakarya.2011

Mudjia Rahardjo, Studi Kasus dalam Penelitian Kualitatif: Konsep dan Prosedurnya.Malang: Pascasarjana UIN Maulana Malik Ibrahim.2017

Ridwan,Fajar, A.,\& Awaluddin. (2019). Penerapan Metode Bernyanyi dalam MeningkatkanPenguasaan Mufradatdalam PembelajaranBahasa Arab di Raodhatul Athfal. Jurnal Didaktika: Jurnal Kependidikan Fakultas Tarbiyah IAIN Bone. Vol. 13, No. 1. 